\title{
Silver and bronze standards and the date of P.Heid. VI 383*
}

\author{
Christelle Fischer-Bovet (Los Angeles) and Willy Clarysse (Leuven)
}

\begin{abstract}
Studies on the change in prices in late third century Egypt are based on a small sample of texts difficult to date. If CPR XVIII and P.Heid. VI 383, where the silver standard is used, belong to the reign of Ptolemy III, as is argued here, the date of 211/210 proposed by Reekmans may be maintained against recent criticism.
\end{abstract}

Keywords: Silver and bronze prices, Ptolemaic monetary history, cleruchs

For more than half a century the monetary changes at the end of the third century $\mathrm{BC}$ have drawn the attention of papyrologists and economic historians, but the end result is still far from certain. Between 220 and $200 \mathrm{BC}$ prices and wages in Ptolemaic Egypt multiplied by a factor of about 60 . As recently stressed by $\mathrm{S}$. von Reden, however, "not only are there serious gaps in the evidence - reliable price data for the period between 220 and 204 are almost absent - but there seem to have been different developments taking place at the same time"1.

The first study on the subject by F. Heichelheim, Wirtschaftliche Schwankungen der Zeit von Alexander bis Augustus, Jena 1930, pp. 9-27 is superseded by the far more detailed articles of T. Reekmans, 'Monetary history and the dating of Ptolemaic papyri', Studia Hellenistica 5, Leuven 1948, pp. 15-43 and 'The Ptolemaic copper inflation', Studia Hellenistica 7, Leuven 1951, pp. 61-119. Reekmans fixed the date of the main monetary change at $211-210 \mathrm{BC}^{2}$ and saw this as the result of Ptolemaic monetary policy: from that year on prices were no longer reckoned in silver but in bronze. In the preceding years prices more or less doubled and this too he saw as a policy measure rather than as a real rise in prices. Following his view W. Clarysse and E. Lanciers, 'Currency and the dating of demotic and Greek papyri from the Ptolemaic period', Anc. Soc. 20 (1989), pp. 117-132, dated several Greek and demotic papyri on the basis of the prices and wages mentioned in them. In his recent book Bronze und Silber, K. Maresch, though focusing on developments in the second century, accepts $210 \mathrm{BC}$ as a watershed (see e.g. pp. 18 and 21), though he points out that the "bronze standard" was perhaps already used shortly before that date and the "silver standard"

\footnotetext{
* We thank Dorothy J. Thompson for her useful comments upon an earlier draft of this article.

${ }^{1}$ S. von Reden, Money in Ptolemaic Egypt, Cambridge 2007, p. 71.

2 Reekmans 1948, pp. 19-23, confirmed by Reekmans 1951, pp. 69-77.
} 
continued for some years afterwards ${ }^{3}$. His examples for a more gradual change, including P.Heid. VI 383 (p. 21 n. 3) and UPZ I 77 (pp. 62-64) are, however, doubtful. H. Cadell and G. Le Rider, Prix de blé et numéraire dans l'Egypte lagide de 305 à 173, Pap. Brux. 30, Brussels 1997, deal only with grain prices. On the basis of increasing penalty prices in land lease and loan contracts they accept a doubling of the wheat price around 221-216 BC (pp. 60-63), and then see a gradual inflation (not a monetary policy) in the following years. They avoid the terms "silver and bronze standard" and do not consider the year 211-210 BC as a watershed.

Since the discussion is necessarily based on the few well-dated texts containing explicit prices for common goods, each of the above authors, from Heichelheim to Cadell/Le Rider, presents a list of useful texts. These lists, however, have serious shortcomings: most texts containing a regnal year do not explicitly identify the king and may therefore be shifted from one reign to another; prices for wine and wages may diverge widely, and to a certain extent this is even possible for wheat prices; when penalty sums for wheat and olyra rise from $4 \mathrm{dr}$./ dr. in the mid third century to $10 \mathrm{dr} / 4 \mathrm{dr}$. in $216 \mathrm{BC}$, this may be the result of rising prices, but also of stricter conditions in the contracts ${ }^{4}$.

On the basis of the lists of our predecessors 5 the following table offers a survey of the more trustworthy sources for prices of basic products during the period 220-200 BC. Certain dates and certain prices have been indicated in bold (penalty prices are not in bold). They are few indeed, and the many texts of years 12-14, usually attributed to $210-208$, are in fact all more or less uncertain.

\begin{tabular}{|l|l|l|l|l|l|l|}
\hline & year & date & reference & price & Maresch & $\begin{array}{l}\text { Cadell/ } \\
\text { Le Rider }\end{array}$ \\
\hline 1 & $16-17$ & 231 & CPR XVIII 1 & $\begin{array}{l}\text { wages of a flute- } \\
\text { player, 40 dr. } \\
\text { per month }\end{array}$ & p. 76-78 & p. 54-56 \\
\hline 2 & 16 & 231 & $\begin{array}{l}\text { CPR XVIII } \\
5.93\end{array}$ & $\begin{array}{l}\text { wine 4 dr. per } \\
\text { chous }\end{array}$ & p. 78 & p. 55 \\
\hline 3 & 4 & $\mathbf{2 1 8}$ & P.Ent. 34 & $\begin{array}{l}\text { wine, 2 dr. 2 ob. } \\
\text { per chous }\end{array}$ & p. 187 & \\
\hline 4 & 7 & $\mathbf{2 1 6}$ & $\begin{array}{l}\text { BGU VI } \\
1262\end{array}$ & $\begin{array}{l}\text { penalty, wheat } \\
\mathbf{1 0} \text { dr. }\end{array}$ & p. 184 & p. 28 \\
\hline
\end{tabular}

${ }^{3}$ K. Maresch, Bronze und Silber. Papyrologische Beiträge zur Geschichte der Währung im ptolemäischen und römischen Ägypten bis zum 2. Jahrhundert n.Chr., Papyrologica Coloniensia 25, Opladen 1996.

${ }^{4}$ On the uncertainty of penalty sums for the study of prices, see Bagnall's review of Cadell/Le Rider, Swiss Numismatic Review 78 (1999), p. 199-200.

5 Reekmans 1951, pp. 107-118; Maresch 1996, pp. 181-205 passim; Cadell/Le Rider 1997, pp. 30-31. 


\begin{tabular}{|c|c|c|c|c|c|c|}
\hline 5 & 8 & 215 & $\begin{array}{l}\text { BGU VI } \\
1264 ; \mathrm{X} \\
1959 ; 1969\end{array}$ & $\begin{array}{l}\text { penalty, wheat } \\
\mathbf{1 0} \mathbf{d r} \text {. }\end{array}$ & p. 184 & $\begin{array}{l}\text { p. } 29 \text { and } \\
33-34\end{array}$ \\
\hline 6 & 8 & 215 & $\begin{array}{l}\text { BGU VII } \\
1277 ; 1278\end{array}$ & $\begin{array}{l}\text { penalty, olyra } \\
\mathbf{4} \mathbf{d r} \text {. }\end{array}$ & p. 186 & $\begin{array}{l}\text { p. } 30 \text { and } \\
32\end{array}$ \\
\hline 7 & 9 & 214 & $\begin{array}{l}\text { BGU VI } \\
1265 ; \\
\text { P.Frankf. } 1\end{array}$ & $\begin{array}{l}\text { penalty, wheat } \\
\mathbf{1 0 ~ d r . ~}\end{array}$ & p. 185 & $\begin{array}{l}\text { p. } 35 \text { and } \\
37\end{array}$ \\
\hline 8 & 9 & 214 & BGU X 1944 & $\begin{array}{l}\text { penalty, wheat } \\
\mathbf{1 0 ~ d r . ~} \\
\text { penalty, olyra } \\
\mathbf{4} \mathbf{d r} \text {. }\end{array}$ & p. 185,186 & p. 36 \\
\hline 9 & 9 & 214 & $\begin{array}{l}\text { BGU XIV } \\
2397\end{array}$ & $\begin{array}{l}\text { penalty, wheat } \\
\mathbf{1 2} \mathbf{d r} \text {. }\end{array}$ & p. 185 & p. 38 \\
\hline 10 & 10 & 213 & BGU X 1946 & $\begin{array}{l}\text { penalty, wheat } \\
\mathbf{1 0} \mathbf{d r} \text {. }\end{array}$ & p. 185 & p. 39 \\
\hline 11 & $\begin{array}{l}\text { no } \\
\text { year }\end{array}$ & $\begin{array}{l}\text { before } \\
211 ?\end{array}$ & $\begin{array}{l}\text { UPZ } 1 \\
149.12,15\end{array}$ & $\begin{array}{l}\text { wine, } 4 \mathrm{dr} \text {. and } \\
4.5 \mathrm{dr} \text {. per chous } \\
\text { price of silver } \\
\text { stater is } 16 \\
\text { bronze dr. }\end{array}$ & $\begin{array}{l}\text { p. } 187^{6} \text { and } \\
195\end{array}$ & p. $52-54$ \\
\hline 12 & 12 & $210 ?$ & $\begin{array}{l}\text { P.Strasb. } \\
103-108\end{array}$ & $\begin{array}{l}4.5 \mathrm{ob} \text {. or } 9 \mathrm{ob} . \\
\text { for soldiers' } \\
\text { daily pay (?) }\end{array}$ & $\begin{array}{l}\text { Clarysse/ } \\
\text { Lanciers, } \\
\text { p. } 127-132\end{array}$ & \\
\hline 13 & $12 / 13$ & $210 ?$ & $\begin{array}{l}\text { P.Teb. III } \\
770\end{array}$ & $\begin{array}{l}\text { loan contract of } \\
1,500 \mathrm{dr} \text {. (silver, } \\
\text { pace Reekmans) }\end{array}$ & $\begin{array}{l}\text { Reekmans, } \\
\text { p. } 20\end{array}$ & \\
\hline 14 & 12 & $210 ?$ & $\begin{array}{l}\text { P.Teb. III } \\
884\end{array}$ & $\begin{array}{l}\text { prices in obols } \\
\text { (silver), but also } \\
\text { in talents } \\
\text { (bronze?) }\end{array}$ & $\begin{array}{l}\text { Reekmans, } \\
\text { p. 19; } \\
\text { Maresch, } \\
\text { p. } 22\end{array}$ & \\
\hline 15 & 12 & $210 ?$ & $\begin{array}{l}\text { BGU VI } \\
1495\end{array}$ & $\begin{array}{l}\text { private account, } \\
\text { bronze (large } \\
\text { amounts) }\end{array}$ & $\begin{array}{l}\text { Reekmans, } \\
\text { p. } 20\end{array}$ & \\
\hline 16 & 12 & $210 ?^{7}$ & O.Mich. 1 & $\begin{array}{l}\text { private account } \\
\text { bronze (large } \\
\text { amounts; daily } \\
\text { wage of } \\
\left.20 \mathrm{dr}^{8}{ }^{8}\right)\end{array}$ & $\begin{array}{l}\text { Reekmans, } \\
\text { p. } 20 \text {; } \\
\text { Maresch, } \\
\text { p. } 193 \text { and } \\
\text { n. } 67\end{array}$ & \\
\hline
\end{tabular}

\footnotetext{
${ }^{6}$ See also Reekmans 1951, pp. 65-67; S. von Reden 2007, p. 71.

7 The editors date the text to $235 \mathrm{BC}$, but Reekmans links this ostracon to the group BGU VII 1500-1562; see also Clarysse, CdE 51 (1976), p. 163 and Maresch 1996, p. 193 n. 67-68.

${ }^{8}$ For the daily wage of 20 dr., see Maresch 1996, p. 193 n. 68.
} 


\begin{tabular}{|l|l|l|l|l|l|l|}
\hline 17 & 13 & $\begin{array}{l}209 \text { or } \\
192\end{array}$ & $\begin{array}{l}\text { SB XXIV } \\
15938\end{array}$ & sum of 500 dr. & & \\
\hline 18 & $13-18$ & $\begin{array}{l}210- \\
204 \text { or } \\
193- \\
187 ?^{9}\end{array}$ & $\begin{array}{l}\text { BGU VII } \\
1500-1562\end{array}$ & $\begin{array}{l}\text { bronze (large } \\
\text { amounts) }\end{array}$ & p. 99 & $\begin{array}{l}\text { p. 31 no. } \\
45-46\end{array}$ \\
& & $\begin{array}{l}208 \text { or } \\
191\end{array}$ & $\begin{array}{l}\text { P.Köln V } \\
220\end{array}$ & $\begin{array}{l}\text { bronze } \\
(700 \text { dr. })\end{array}$ & p. 187 & \\
\hline 19 & 14 & & & & \\
\hline
\end{tabular}

The date of the first two items in the list, which are dated to year 16, financial year 17 of an unnamed king, is debated. B. Kramer convincingly attributed this long papyrus roll to the reign of Ptolemy III Euergetes on the basis of a prosopographical argument: Attinas son of Kalliphanes from Ainos, the syngraphophylax in CPR XVIII 30 is certainly identical with the homonymous witness in P.Petrie Wills 16, dated 236/235 BC. In CPR XVIII 30 he is 40 years old; in the Petrie will the age is lost in a lacuna. Maresch prefers a date under Ptolemy IV Philopator (206 BC). If year 16 of the CPR text is attributed to Ptolemy III, Attinas was about 35 years when he witnessed the Petrie will; if we attribute the 16th year to Ptolemy IV, i.e. to 206 BC, he would be merely 11 years in 236 BC. Though Maresch points out that age indications are not always exact, such a huge mistake is unlikely (the earliest known age for a witness is 18 years, cf. P. Petrie Wills, p. 188). In this case the prosopographical argument has precedence over the monetary problems discussed by Maresch. The high wine price of $4 \mathrm{dr}$. a chous in CPR XVIII 30, for instance, may be due to the quality of the wine and would in fact be too low for a date in $206 \mathrm{BC}$, when a price in bronze reckoning is expected. Nor is the argument from the calendar decisive, as Maresch p. 79 himself concedes ${ }^{10}$. Cadell/Le Rider, pp. 54-56 ${ }^{11}$, who follow Maresch's date, offer an extra argument in the monthly payment of $400 \mathrm{dr}$. to a flute-player in CPR XVIII 1. This, however, is based on an erroneous translation of the word $\tau \varepsilon \sigma \sigma \alpha \rho \alpha$ ó $о \nu \tau \alpha$, which means 40 not 400 . A monthly wage of $40 \mathrm{dr}$. for a professional flute-player (he will take part in agônes) is not problematical in $236 \mathrm{BC}$.

We have not included in the above list P.Heid. VI 383, which constitutes a more difficult problem. This is a receipt in letter form ( $\chi \alpha i$ petv) for the sale in

\footnotetext{
9 The editors prefer Euergetes (235-230 BC) to Philopator (210-204 BC) on palaeographical grounds; Reekmans 1948, p. 20 and 1951, p. 69 n. 2, following Heichelheim, dates to Philopator "on palaeographical grounds"; Cadell/Le Rider 1997, pp. 47-48 choose Epiphanes, but their argument is based on the date of P.Heid. 6 383, which is itself uncertain. Maresch, p. 99 leaves the choice between Philopator and Epiphanes open. The script of BGU 1532 (plate in Maresch p. 102) looks third rather than second century, as already seen by the first editors.

${ }^{10} \mathrm{C}$. Bennett, whom we consulted on this matter, also prefers a date under Ptolemy III. The register is dated to Pharmouthi (?) [the reading is uncertain] of year 16, financial year 17 (1.3). The individual contracts are dated by Macedonian months, but there are no Greek-Macedonian double dates, so that the two calendars cannot really be compared.

${ }^{11}$ And also by S. von Reden 2007, pp. 182-194 passim.
} 
advance ("Lieferungskauf") of 500 artabas of wheat for $3000 \mathrm{dr}^{12}$. The text is dated in a 14th year, which the editor attributes to the reign of Ptolemy IV Philopator (October 209 BC). The financial year used in 11. 11-12 excludes a later date.

Seller is the Mysian Olympos, a cleruch and cavalryman of the fifth hipparchy, buyer is Ptolemaios, also a cleruch and a member of the same military unit. From other texts we know that Olympos had his kleros in the village of Oxyrhyncha. The wheat price of 3000 dr., i.e. 6 dr. per artaba is indeed more than expected for the period of Euergetes when the wheat price is between 1 and $3 \mathrm{dr}$. per artaba, but it is far less than in the second century, when prices are calculated in bronze and not in silver. This very text is used by the editor R. Duttenhöfer (P.Heid. VI, p. 157) and by H. Cadell/G. Le Rider, p. 43 no. 40 as the main witness against Reekmans' date of 210 BC (year 12) as the start of the bronze reckoning. They compare this price with the penalty prices for grain, which usually double the market price and amount to 10 and $12 \mathrm{dr}$. in the period 216-213 BC.

The Mysian cleruch Olympos son of Antipatros, who belongs to the company of Ptolemy son of Nautas, is listed in F. Uebel, Die Kleruchen, no. 637 and in PP $\mathrm{X}$ E1888. One of the references given for him (see following list) is certainly dated to 217 , another to 171 . The date of the first text is certain, because it mentions the dioiketes Theogenes (Pros. Ptol. VIII 32), who was in office about 217/216 $\mathrm{BC}^{13}$. The last text has a full dating formula with eponymous priests. If Olympos is the same person in all five texts ${ }^{14}$, both his career $(217-171 \mathrm{BC})$ and that of the eponymous officer Ptolemaios son of Nautas (235-209 BC) were very long.

1) year $\mathbf{5}=\mathbf{2 1 7}=\mathrm{SB} X X 15068$ (son of Antipatros, Mysian, hekatontarouros, company of Ptolemaios son of Nautas)

2) year $14=209=$ P.Heid. VI 383 (no patronymic, Mysian, hekatontarouros, company of Ptolemaios son of Nautas)

3) year $15=207=$ P.Heid. VI 373 (no ethnic nor patronymic, no eponymous officer, but hekatontarouros)

4) year $4=178 / 177,167 / 166$ or $150 / 149=$ P.Tebt. III 1001 Vo, 1.43 (owner of 100 arourae; no ethnic nor patronymic nor eponymous officer)

5) year $\mathbf{1 0}=\mathbf{1 7 1}=$ P.Tebt. III 819 (son of Antipatros, Mysian, hekatontarouros, no eponymous officer)

We prefer to distinguish two homonymous persons and to attribute numbers 4

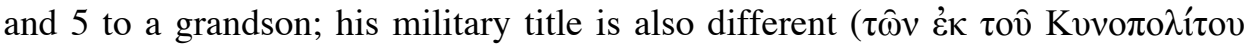

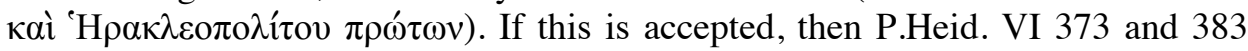
may be dated under Ptolemy III, resulting in the following picture:

\footnotetext{
12 The payment of 3000 drachmas is only preserved on the verso and slightly damaged, but the reading seems certain because it also fits the lacuna in 1.8 ( $\chi 1 \lambda$ ías would be too short there).

${ }^{13}$ B. Kraut, 'Hypomnema to Theogenes the Dioiketes', ZPE 80 (1990), pp. 273-276 (= SB 20 15068) and P.Köln XI, pp. 83-84.

14 So F. Uebel, Die Kleruchen Ägyptens unter den ersten sechs Ptolemäern, Berlin, 1968, no 637, R. Duttenhöfer, P.Heid. VI, p. 76-77 and Pros. Ptol. X E 1888.
} 
1) year $14=234=$ P.Heid. VI 383 (no patronymic, Mysian, hekatontarouros, company of Ptolemaios son of Nautas)

2) year $15=233=$ P.Heid. VI 373 (no ethnic nor patronymic, no eponymous officer, but hekatontarouros)

3) year $\mathbf{5}=\mathbf{2 1 7}=\mathrm{SB} X X 15068$ (son of Antipatros, Mysian, hekatontarouros, company of Ptolemaios son of Nautas)

4) year $4=178 / 177,167 / 166$ or $150 / 149=$ P.Tebt. III 1001v, 1.43 (owner of 100 arourae; no ethnic nor patronymic nor eponymous officer)

5) year $\mathbf{1 0}=171=$ P.Tebt. III 819 (son of Antipatros, Mysian, hekatontarouros, no eponymous officer)

P.Heid. VI 383 is written in a third century hand, which fits Euergetes as well as Philopator, the time distance being too small to use the palaeography as an argument in either direction. The advantage is that the career of Ptolemaios son of Nautas is much shorter and does indeed come to an end before the battle of Raphia like that of his colleagues (see the article above).

The earlier date, however, entails a second prosopographical reshuffling. In P.Heid. VI 373 payment is made to the logeuterion of the city: $\pi \dot{\varepsilon}(\pi \tau \omega \kappa \varepsilon v) \dot{\varepsilon}[\pi] \grave{i}$

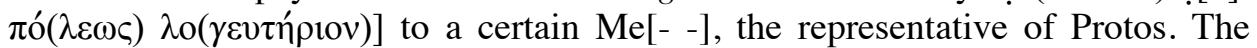
editor identifies Protos with the homonymous banker Pros. Ptol. I 1262, who is attested in several other texts. One of these texts is certainly dated to $204 \mathrm{BC}$ (Theogenes is mentioned as a predecessor of a new dioiketes Dorion). The references can be presented as follows:

$\begin{array}{llll}\text { year 12-13-14 } & 210-208(?) & \text { Bogaert }^{15}, \text { p. 319 } & \text { banker in Krok. polis } \\ \text { year 15 } & 207 & \text { P.Heid. VI 373 } & \text { logeuterion in Krok. polis } \\ \text { year 18 } & \mathbf{2 0 4} & \text { SB XX 14069 } & \text { banker in Krok. polis } \\ \text { no year } & \text { late III } & \text { P.Tebt. III 984 } & \text { logeuterion in Mouchis }\end{array}$

If our new dates are accepted the above table has to be changed as follows:

$\begin{array}{llll}\text { year 15 } & 233 & \text { P.Heid. VI 373 } & \text { logeuterion in Krok. polis } \\ \text { year [2]1 (?) } & 227(?)^{17} & \text { P.Tebt. III 984 } & \text { logeuterion in Mouchis } \\ \text { year 12-13-14 } & 210-208(?) & \text { Bogaert, p. 319 } & \text { banker in Krok. polis } \\ \text { year 18 } & \mathbf{2 0 4} & \text { SB XX 14069 } & \text { banker in Krok. polis }\end{array}$

In our view, like P.Tebt. III 984, P.Heid. VI 373 belongs to the reign of Euergetes. At that time Protos was head of the logeuterion in Krokodilon polis as well as in Mouchis. Protos the banker of Krokodilon polis worked a generation later; either the same Protos gained promotion or this is a different person (for this

\footnotetext{
15 Cf. R. Bogaert, Trapezitica Aegyptiaca, Papyrologica Florentina 35 (1994), p. 319 with n. 166; see also Bogaert's remarks on p. 349 and 359.

16 This is the date of the editio princeps. G. Casanova introduces a small correction, changing the uncertain year 1 into year [1]1 (Aegyptus 68, 1988, p. 15; see BL IX, p. 360).

17 This is the date proposed by R. Bogaert, ZPE 69, 1987, p. 127 and ZPE 120 (1998), p. 180 (= BL IX, p. 360 and BL XI, p. 281). The cursive writing has a clear third century look.
} 
double possibility, see already P.Heid. VI, p. 76; Bogaert, p. 319 n. 166 also considers Protos the head of the logeuterion in Mouchis to be a different person).

Finally we have to look at the unique wheat price of 6 drachmas per artaba in P.Heid. VI 383. This is indeed far more than 1 to 3 drachmas per artaba, the expected price in 233. Cadell/Le Rider date this price to $209 \mathrm{BC}$ as one more example of the rising price level in the early years of Philopator ${ }^{18}$, whereas von Reden (p. 195 and n. 58) thinks the high figure is due to the changed equivalence between bronze and silver at that time. Duttenhöfer, realising that this price is in any case counted in silver money, not in bronze, concludes that Reekmans' date for the change of "silver standard" to "bronze standard" should be lowered by at least two years. We have no solution for this, but perhaps it has something to do with the type of document, which is a sale on delivery.

\section{Conclusion}

The sudden change in prices at the end of the third century $\mathrm{BC}$, which was dated by Reekmans to the year $211 / 210$ BC is still somewhat of a mystery. Penalty prices for wheat and olyra double in the period 216-214, but this provides no irrefutable proof that real prices also went up, and we have no prices for this period. The numerous texts of year 12 show low prices in silver money and high prices in bronze, but none of them is firmly dated. The most interesting one is probably P.Teb. III 884. This account, consisting of several fragments, starts with figures in drachmas and obols (fragm. 1 and 3 "silver standard") and ends with talents and thousands of drachmas (fragm. 4-6 "bronze standard"). If Maresch, p. 22 is right, 11. 6-7 even contain a calculation from bronze to silver. This may indeed point to year 12 of Philopator $(211 / 210$ BC) as the year of change, with some texts using the old system (nos. 12-13 in the list) and others the new system (nos. 15-16) ${ }^{19}$. If the ostraca from Philadelpheia in Berlin (no. 18 in the list above) do indeed belong to the late third rather than to the early second century (the editors even preferred a date under Euergetes and the only plate available [Maresch p. 102] does indeed show a third century form of script), the change would become visible indeed. But again the regnal year is not identified. The same might be true for P.Heid. VI 383, which is certainly dated by the silver standard, but in view of the career of Ptolemaios son of Nautas and of the cleruch Olympos it seems more plausible that its 14th year belongs to Ptolemy III (234/233) and that the receipt was written on 29 October 234 BC.

\footnotetext{
18 Cadell/Le Rider 1997, p. 43 ("témoignage capital"), 60-61.

${ }^{19}$ Even more uncertain is SB XX 15938 (= P.Heid. VI 380 with new fragment; no. 17 in the above list), where a sum of $500 \mathrm{dr}$. is claimed from an Egyptian priest. It is unclear whether this sum is expressed in silver or bronze and whether the 13th year mentioned in the text is that of Philopator or Epiphanes.
} 